\title{
ENHANCING STUDENTS' COGNITIVE ABILITIES THROUGH STUDENTS-CENTERED LEARNING (SCL)
}

\author{
Faisal Amri dan Nur Ekaningsih \\ Sultan Agung Islamic University of Semarang \\ faisalamriew@gmail.com; nurekaningsih@unissula.ac.id
}

\begin{abstract}
This conceptual paper, presents about the result of discussion regarding students-centered learning improves students' cognitive ability. SCL improves skills by developing cognitive ability lies within them as the first basic skill. It is important for students to have adequate cognitive abilities to keep up the materials which are being taught by teachers. Therefore, this paper will explain about cognitive ability. Cognitive ability which is affecting on learning process, has made some teachers struggle to seek a way how to improve it. There are few methods that have been chosen thoroughly for developing cognitive abilities on students. First is about developing thinking that refers mainly to how students think effectively and creatively. Second is about cooperative learning that refers to how students cooperate or work with other and effect of partners in learning process. Third is about learners 'responsibility that has correlation with students' responsible which affects on objectives of learning.
\end{abstract}

Keywords: Students-Centered Learning, Cognitive Ability, Developing Thinking Skill, Cooperative Learning, Learners'Responsibility.

\begin{abstract}
Abstrak
Artikel ini menyajikan hasil diskusi mengenai students-centered learning untuk meningkatkan kemampuan kognitif siswa. SCL meningkatkan keterampilan dengan mengembangkan kemampuan kognitifyang terletak di dalamnya sebagai keterampilan dasar pertama. Penting bagi siswa untuk memiliki kemampuan kognitif yang memadai untuk menerima materi yang sedang diajarkan oleh guru. Oleh karena itu, tulisan ini akan menjelaskan tentang kemampuan kognitif. Kemampuan kognitif yang berpengaruh pada proses belajar, telah membuat beberapa guru berjuang untuk mencari cara bagaimana memperbaikinya. Ada beberapa metode yang telah dipilih secara menyeluruh untuk mengembangkan kemampuan kognitif pada siswa. Pertama adalah tentang mengembangkan pemikiran yang mengacu pada bagaimana siswa berpikir secara efektif dan kreatif. Kedua adalah tentang pembelajaran kooperatif yang mengacu pada bagaimana siswa bekerja sama atau bekerja dengan orang lain dan pengaruh mitra dalam proses pembelajaran. Ketiga adalah tentang tanggung jawab peserta didik yang memiliki korelasi dengan tanggung jawab siswa yang mempengaruhi pada tujuan pembelajaran.
\end{abstract}

Kata Kunci: Students-Centered Learning, kemampuan kognitif, pengembangan keterampilan berpikir, cooperative learning, tanggung jawab peserta didik. 


\section{Introduction}

Cognitive skills are important factors that determine of outcomes both on economic and social. In one case, cognitive skills have closed correlations with economic growth. Higher cognitive skills can increase health and functioning mental abilities and also related to higher outcomes (Hanushek and Woessmann, 2008; Heckman et al., 2006, or Heineck and Anger, 2010 as cited in Dahmann \& Berlin, 2016). In another case, ones with higher cognitive ability are much easier to meet the requirement to go into school whether to study for the first time or to continue their study (Banks and Mazzonna, 2012 as cited in Dahmann \& Berlin, 2016).

Cognitive abilities are basic skills to be owned at very first place, which are required in the process of learning or the fundamental mental skills and are compulsory for learning (Gibson \& Learningrx, n.d.). Thus, students should have adequate cognitive ability to learn and study in their field. In other words, this is very important for students to have adequate cognitive ability to achieve objective learnings in the school. Thus, it can be said that students without adequate cognitive skill cannot understand the goals of learning or even to achieve objective of learning in order to be more educated student (Grönqvist, Vlachos, 2008 as cited in Sautelle, Arifin, \& Bowles, 2015); Dahmann \& Berlin, 2016).

While cognitive skills are rarely educated overtly in schools, a study shows that education is able to help cognitive skills (Finn et al., n.d.). By giving a suitable teaching method to students or learners, they might give significant improvement by developing their way to thinking. Teaching method plays a significant role to enhance students' learning and creativity (Chen, Wei, \& Hsu, 2007).

Students Centered Learning (SCL) is expected able to improve students' cognitive abilities. Cognitive abilities have relationships with academic performance. Improving academic performance means improving academic skills and cognitive skills determine academic performance (Finn et al., n.d.; Renandya, n.d.). Students Centered Learning has varied definitions (Renandya,n.d.). Felder and Brent (1996) (as cited in Renandya, n.d.) defined SCL as a wide teaching method that comprises active learning, students' responsibility, and cooperative learning. The sole purpose of this method is to make students become lifelong learners that is continuing learning either inside or outside of formal education (Renandya, n.d.)

As its name, Student-Centered learning (SCL) is a way of teaching that mostly used for students. Therefore, many teachers employ this method on their classes. It can improve students' learning development by looking some aspects such as developing thinking skills, cooperative learning, and learners' responsibility that could effect on cognitive abilities. Because students are expected to learn on their own that make them force themselves to think creatively and effectively while facing and figuring out problems. (Renandya, n.d.; Sautelle et al., 2015).

Thus, Cognitive ability is fundamental skills that need to be improved at first place as basic skills while it effects on academic achievement. However, the cognitive ability can be improved with an education; it is by giving a suitable teaching method to students since a teaching method plays a significant role. SCL is highly having probability to improve it since SCL comprises active learning, students' responsibility and cooperative learning then later on students will learn on their own way while facing and figuring out problem during studying which is surely will improve their cognitive ability at the same time they learning (Finn et al., n.d.; Gibson \& Learningrx, n.d.; Renandya, n.d.; Sautelle et al., 2015) 


\section{Review Of Related Literature}

\subsection{Cognitive Ability}

Cognitive ability, or as we know intelligence, is a concept depicts mental and brain of a person based on skills. It has vast description and conceptualized in various ways (Sautelle et al., 2015). In the current study, cognitive ability is defined as a universal mental capacity which comprises several abilities - problem solving, abstract thinking, planning, rapid learning, and learning from experiences (Hunter, Schmidt, 1996, Ones, Dilchert, Chockalingam, 2012 as cited in Sautelle et al., 2015). A few of these studies show the correlation between cognitive ability and career performance (Lang et al., 2010 as cited in Sautelle et al., 2015). Ones with low cognitive ability have effect on performance of goals achieving (Grönqvist \& Vlachos, 2008 as cited in Sautelle et al., 2015). Ones that do not enhance and use their cognitive skills, they are likely having problems with tasks and activities in life (Richard-Gustafson, 2015). Therefore, Students should enhance cognitive ability if not they will have difficulties as facing problems. It also to improve their thinking skills for better understanding of the materials to reach the goals of learning since cognitive ability has correlation with learning process specifically with performance of goals achieving (Hunter, Schmidt, 1996; Ones, Dilchert, Chockalingam, 2012 as cited in Sautelle et al., 2015; Lang et al., 2010 as cited in Sautelle et al., 2015; Grönqvist \& Vlachos, 2008 as cited in Sautelle et al., 2015; RichardGustafson, 2015).

\subsection{Effects of Cognitive Ability on Learning Process}

Cognitive ability is the basic skills that are required in the process of learning. The usage of this cognitive skill is to process and recall knowledge. The knowledge will be stored in brain in which one can distribute knowledge one has already known. Cognitive ability is also process activities in the brain that helps students to learn and build up their knowledge. If they have low cognitive abilities they are more likely to be poor learners, in vice versa if they have high cognitive abilities they will become good learners, so cognitive ability influences on academic performances. (Gibson \& Learningrx, n.d.)

Thus, Cognitive ability is important skill to be owned to process and recall knowledge. It also helps students to learn things and build up knowledge. It has effects on learning or studying, for example, if students have sufficient cognitive ability they will be good learners or otherwise (Gibson \& Learningrx, n.d.)

\subsection{Effects of SCL for Cognitive Ability Development on Students a. Developing Thinking}

Developing thinking is developing the way of thinking to get more understanding and enable students to explore their world (Buttriss \& Callender, 2006). Developing thinking skill can be assumed as critical thinking when it has reached at certain points in which they or students themselves independently learn materials to improve their thinking. (Gotoh, 2016). Hence, teachers should shape students' thinking skill by making students face problems that offers students' chances to exercise and build a foundation for developing thinking and the role as the teachers in their class activity may sometimes is to be a guidance to resolve problems creatively (Renandya, n.d.)

In general, it is agreed that learners should be capable of thinking effectively (Bok, 2006; Halpern, 1993; Jones et al., 1995 as cited in Smith, 2014). It could be run with teachers' guidance in the process of learning by making students have goals or objectives of their learning. Goal has impact on students' motivation and performance (Schunk, 1990 as cited in Chen et al., 2007). These goals can be assumed as students' needs that could be achieved 
by looking the objective learnings. Teachers and teachers' assistant play a significant role to meet students' need (Paper, 2009). However, these days, many students cannot think effectively or even critically while they are studying or learning a subject at the same time. Many factors affect them to reach it, but these factors can be specified into two points. Those would be such as lack of direction and fear of failure.

First of all, students sometimes lack of direction when they do not have goals and objectives in their learning. They need to scheme the goals and objectives since they have significant effects on students' learning progress. Second, fear of failure, however, is one common thing that most students experience in their lives. Students sometimes are not confident enough to complete a task successfully (Andres \& Dobrovská, 2015). It is inevitable certainly for student in a process of learning activity in which they are most likely making mistakes even without knowing it. Perhaps it can be warded off by making preventive, for example, not repeating the same mistake, start with the right thing, focusing on the subject, and trying to make better for your live. Those may help to avoid making mistakes.

In short, developing thinking is the set of skills which enable one to solve problem logically or a skill that must be evolved at the first place in order to achieve objective learning or to get more understanding in a process of learning activities. The goals of learning can be assumed as students' need. In this case, teachers need to make students to scheme goals and objectives since goals have impacts on students' motivation and performance which make them to think critically and effectively. To do so, teachers and teachers' assistant have important roles to meet the needs of students. (Gotoh, 2016; Buttriss, Callender, 2006; Bok, 2006, Halpern, 1993, Jones et al., 1995 as cited in Smith, 2014;Schunk, 1990 as cited in Chen et al., 2007;Paper, 2009).

\section{b. Cooperative learning}

Cooperative learning happens when two individuals work together in a group in order to increase the outcomes of individual and peer or two or more students are learning together to do a task or an activity in order to complete it (Johnson, Johnson, 1989, Siegel, 2005 cited in Adams, 2013)

This method can be employed as students interacting with others, while the lecture does not talk much and teacher give guidance to students. In addition, teacher should give direction by monitoring students as they interact each other and sometimes need to intervene by giving praises, corrections, questions, and motivations (Renandya, n.d.)

Learning is not the only thing you can do yourself. In fact, learning can be done alone, but if one learns with a friend then they will get different things like different perspective or a different pattern thinking although looking at the same thing. If students participating in active learning they involved in learning process they tend to and do not rely on teachers (Petress, 2008). The development of students' ability to think and work together to solve problems is an important factor in education (Gotoh, 2016)

Students should do cooperative learning. There are many reasons why students should do this cooperative learning (Renandya, n.d.). First, students' lack of motivation to think by themselves is a problem that happens almost all students, so if cooperative learning conducted in their learning activity it will evoke their motivation to think. Second, narrow perspective on a thing is one of students lack of ability. So if this cooperative learning employed in their activity it will help them to think more detail on a thing or by specifying the thing, because people have different perspectives or different patterns of thinking on a thing that they perceive by their senses. 
Students can do this cooperative learning by discussing a topic. They can discuss with a partner or work in a group. Discussion is an attractive way to attract students' interest and able to engage and to interact students with others in process of learning within discussion. (Brookfield, Preskill, 1999, Finkel, 2000, McKeachie, 2002 as cited in Jones, 2014). Discussion is important thing that student should do to improve their thinking patterns on a thing. The last thing of this cooperative learning that students should know is students are expected to be able work in a group.

\section{Learners' Responsibility}

Learner's responsibility is, according to Rebenius (1998), the ability "to plan, accomplish and evaluate work". Responsibility is a foundation of learning for students. Students are most likely will not study or unwillingly study because they are not responsible for their studying and it effects on their process of learning and identified students' responsibility as a primary goal of learning (Sternberg, 2001 as cited in Fishman, 2014).

However, how students want to study if they do not know why they are studying, what they are studying and what is the purpose of the course (Renandya, n.d.). Most students lack of understanding of the objectives of their learning that is why learners' responsibility is important. However, these matters can be resolved with these means as follows: Establishing learning goal, identify own strength and weakness and seek opportunity for learning that build self-concept as a learner (Skills, n.d.)

Thus, students need to have in learning and studying in order to do works and considered responsibility as a primary of goal learning. To do so, for starting, students need to know the purpose why they are learning and what is the purpose of studying and the course. Then, for finishing, students need to know some means of learning to emerge responsibility such as establishing learning goal, identify own strength and weakness and seek opportunity for learning that build self-concept as a learner. Gradually, the responsibility will emerge on students (Sternberg, 2001 as cited in Fishman, 2014; Rebenius 1998; Renandya, n.d.; Skills, n.d.)

\section{Discussion}

Many students have varied problems during learning or studying, this is because they cannot think critically, creatively, and effectively. Many factors might affect them, but the main factor that has high probability to be the source of this case is having lack cognitive ability. Having insufficient cognitive ability is a problem that almost many students experience. One study shows that cognitive ability has closed correlation with academic achievement, especially in performance (Hunter, Schmidt, 1996; Ones, Dilchert, Chockalingam, 2012 as cited in Sautelle et al., 2015).

In this case, students need to get a teaching method that is able to improve their cognitive ability. A teaching method that is suitable for their studying. one method that is able to improve cognitive ability is Student Centered Learning (SCL), in which students can improve their own learning which stimulates the brain to think creatively, effectively and critically. By using this method students are able to improve their cognitive ability gradually to have sufficient cognitive ability in order to be good learners.

Having sufficient cognitive ability helps students to understand the big picture of objective learnings that will help them to meet the academic achievement. It will make students easier to master any skills in learning process because cognitive ability is the basic skill to be owned at the very first place. It also helps them to understand the lesson which is 
being taught in a class. Lastly, they will have better education for study since they understand and master any materials and skills.

\section{Conclusion}

Students-Centered Learning (SCL) is a suitable method for teaching to improve cognitive ability development on students. Putting students as a center of leaning process will force students to think effectively, creatively and critically. In order to fulfill students' needs to meet academic achievement, students need to improve their cognitive ability. By improving cognitive ability students will get the main purpose of studying by targeting academic achievement as objective learnings. Cognitive ability also gives effects on students' performance in process of learning. Cognitive ability can be improved by few elements in SCL, those are developing thinking, cooperative learning and learners' responsibility. The elements themselves are likely will improve cognitive ability of students if they are implemented in a right way.

\section{References}

Adams, A. R. (2013). COOPERATIVE LEARNING EFFECTS ON THE CLASSROOM.

Andres, P., \& Dobrovská, D. (2015). Procrastination: One of the worst enemies?, (September), 102-104.

Chen, N., Wei, C., \& Hsu, F. (2007). Impact of Process Goal and Outcome Goal on Learning Performance for Web-based Learners, (Icalt), 2-3.

Dahmann, S. C., \& Berlin, D. I. W. (2016). How Does Education Improve Cognitive Skills ? Instructional Time versus Timing of Instruction.

Finn, A. S., Kraft, M. A., West, M. R., Leonard, J. A., Bish, C. E., Martin, R. E., ... John, D. E. (n.d.). Cognitive Skills , Student Achievement Tests , and Schools, 1-26.

Fishman, E. J. (2014). With great control comes great responsibility: The relationship between perceived academic control, student responsibility, and self-regulation, 685-702. https://doi.org/10.1111/bjep.12057

Gibson, K., \& Learningrx, C. E. O. (n.d.). Teacher Introduction Determining Your Students 'Weaknesses, 1-10.

Gotoh, Y. (2016). DEVELOPMENT OF CRITICAL THINKING WITH, (Celda), 353-356.

Jones, J. M. (2014). Discussion Group Effectiveness is Related to Critical Thinking through Interest and Engagement, 13(1), 12-24.

Paper, C. J. (2009). Roles and Responsibilities of Teachers and Teacher Assistants / Education Assistants.

Renandya, W. A. (n.d.). Language Teaching Today.

Sautelle, E., Arifin, D. N., \& Bowles, T. (2015). Personality, Resilience, Self-Regulation and Cognitive Ability Relevant to Teacher Selection, 40(4).

Skills, L. (n.d.). Take Responsibility for Learning Objectives :, (Appendix II), 61-66.

Smith, G. F. (2014). Journal of Management Education. https://doi. org/10.1177/1052562913489028 